\title{
Public-Private Financed Road Infrastructure Development in North-Central Region of Nigeria
}

\author{
Adamu Mudi ${ }^{1}$, John Lowe ${ }^{1}$ \& David Manase ${ }^{1}$ \\ ${ }^{1}$ Department of Construction and Surveying, School of Engineering and Built Environment, Glasgow \\ Caledonian University, UK \\ Correspondence: Adamu Mudi, Department of Construction and Surveying, School of Engineering and Built \\ Environment, Glasgow Caledonian University, G4 OBA, UK. E-mail: mudi.adamu@gcu.ac.uk
}

Received: October 29, 2015

Accepted: November 13, 2015 Online Published: November 30, 2015

doi:10.5539/jms.v5n4p58

URL: http://dx.doi.org/10.5539/jms.v5n4p58

\begin{abstract}
The development and provision of road infrastructure in Nigeria has primarily been through the traditional forms of procurement strategies by the federal, state and local governments through budgetary allocations and door-financed loans and grants this thereby leaves the Nigerian road sector in a precarious situation. In recent time, with the demand for more road infrastructure arising from the population explosion and urban-rural migration coupled with the financial crisis experienced by the Federal Government resulting from global economic and financial crisis the Federal Government of Nigeria therefore sought to involve the private sectors in the development of road infrastructure facilities via Public-Private Partnerships (PPPs) like the developed countries so as to meet their economic growth.

This paper examined the state of road infrastructure development through Public-Private Partnerships in North-Central Region of Nigeria with emphasis on the strengths and limitation of PPPs. The chapter begins with a review of literature on the concept of PPP road infrastructure development in North-Central Region of Nigeria. Academic literatures were also reviewed on PPP objectives, operational and financial characteristics in road infrastructure development in North-Central Region of Nigeria this was followed with the assessment of the PPP road infrastructure development life-cycle process and its challenges.
\end{abstract}

Keywords: effective, efficient, framework, public-private partnerships, development, strategy, institutional and regulatory

\section{Background}

The importance of road infrastructure to non-income aspects of poverty, improvements in health, education and social cohesion, cannot be overemphasized. The strong national growth is always a function of adequate and well-functioning road infrastructures that underscores both the production and free flow of goods and services within and outside a country. However road infrastructure developments in the north-central Nigeria have historically been driven primarily by perceived deficiencies but in recent time according to Obozuwa (2013) road infrastructure development in Nigeria has assumed a central importance in the fight to attain a social and economic stability, ibid further opined that the federal and many state governments in Nigeria are using infrastructure as the focal point of their administrations and policy enactments in view of this, there is therefore the need for the development of road infrastructure base in Nigeria comparable to those of other developed nations in the world. In view of this according Omisore (2014) the Central Bank of Nigeria (CBN) estimated that the Federal Government of Nigeria will require US\$100bn of investment in infrastructure development over the next ten (10) years coupled with the Nigerian population growth and demands for infrastructural facilities out of which US\$14bn will be for road maintenance and development investment in Nigeria.

Road infrastructure in north-central region of Nigeria does not only represent a substantial share of the economy, but also plays an essential role in supporting nearly all aspects of the Nigerian society's operation. According to a report; Reforming Road Transportation in Nigeria (2009) cited in Federal Ministry of Work (2013), Nigeria ranks tops compared with other countries in Sub-Saharan Africa in terms of road network. North-Central Nigeria has the largest road network in Nigeria being the seat of the Federal Government with an estimated 58,000km of road network made up of $18,000 \mathrm{~km}, 15,000 \mathrm{~km}$ and $25,000 \mathrm{~km}$ for Federal, State and Local Government respectively which were grouped as Trunk A, B and C; connecting villages to cities, the distant with the near and 
the inter- land with the urban market (FMW, 2013; Adamu et al., 2015). In order to catalyse the present rate of growth and development of the economy in north-central region of Nigeria, the requisite road infrastructure must be put in place so as to justify the need to enhance road infrastructure to support the expanding population in north-central region of Nigeria.

However, the nearly exclusive concentration of road infrastructure provision in the hands of the public sector, especially in north-central region of Nigeria, has led to the failures in the delivery of many road infrastructure facilities in the zone (Adamu et al., 2015). Faced with the declining economic fortunes and dwindling revenue, most state government in the north-central Nigeria increasingly found it very difficult to keep pace with the development and maintenance of road infrastructure. Hence the perception of both the federal and state government that these economic infrastructures were social services affects the investment in the road infrastructure and consequently the effectiveness of their provision. Similarly, the traditional inefficiency associated with public sector monopolies in charge of the road infrastructure development affects the quality and reliability of services provided by the public sector in road infrastructure development (Adenikinju, 2003; Adamu et al., 2015).

\section{Road Infrastructure Development through PPPs in North-Central Region of Nigeria}

In north-central region of Nigeria, the sustainable growth and development of the zone hinges greatly on the provision and maintenance of adequate road infrastructure. Because the socio-economic development in the zone goes as far as road infrastructure improvement can attain. The current state of road infrastructure in north-central region of Nigeria poses a significant problem; and the financing gap has proven to be the thorn in the flesh of the efforts to alleviate the road infrastructure problem in the zone. The Federal and State Government in the zone therefore took a bold step to embark on Public-Private Partnership (PPP) initiatives gear towards tackling the current and impending challenges facing the development of road infrastructure in north-central region of Nigeria. Typically, one or more private sector companies forms a consortium in the PPP transaction and are generally described as "Special Purpose Vehicle" (FMW, 2013; Adamu et al., 2015). The consortium may mainly consist of a project sponsor, Bank lender etc, the consortiums were responsible for the technical, financial, legal, environmental and social aspects of PPP transaction in the road infrastructure development in the zone. Dada \& Oladokun (2012) noted that Public-Private Partnership strategies has an underlying philosophy of integrating design and construction in the context of the Nigerian construction industry, the pervasive effect of the PPPs across many sectors and even in the provision of road infrastructure differentiates the strategy from other development strategies in the Nigerian construction industry.

However, the non-availability of long-term funds, absence of risk sharing structures, lack of clarity around the governance and implementation of the PPP framework, and a dearth of expertise to assist banks and other firms' engagement in road infrastructure financing, are some of the challenges that are hampering the development efforts of road infrastructure under PPPs in Nigeria and most especially in north-central region of Nigeria (Sanusi, 2012). As a result of this in most case, the Federal and States Government in north-central region of Nigeria has been the sole financier of the road infrastructure projects and has often taken responsibility for implementation, operation and maintenance of the road infrastructure as well (Ndubisi, 2012; Adamu et al., 2015).

In view of this, the Federal and States Government in north-central region of Nigeria have to identify a workable approach in tackling road infrastructure development challenges by harnessing the economic gains of an enhanced road network (FMW, 2013). As a proactive approach according to FMW (2013), the Federal and States Government in the north-central Nigeria has also embarked on road infrastructure sector reforms which is aimed at improving service delivery in road development, enhance management capacity, conducive institution, legal and regulatory framework through a joint participation with the private sector in the development, financing and management of road infrastructure development in north-central region of Nigeria. It is the Government's expectation that private sector participation in road infrastructure development through PPP will enhance efficiency, broaden access, and improve the quality of public services in road development in north-central region of Nigeria.

In the demonstration of the Federal and States Government commitment and zeal toward achieving their objectives in road infrastructure provision as part of Government policy, the Federal Government of Nigeria further established the Infrastructure Concession Regulatory Commission (ICRC) through the ICRC Act in the year, 2005 (FMW, 2013). Furthermore, FMW (2013), stated that the ICRC serve as an agency of the Federal Government of Nigeria responsible for regulating Public-Private Partnerships (PPPs) in the implementation of a world class PPP framework towards the development of a world class Brown-Field and Green-Field road 
infrastructure facilities for the benefit of Nigerians and the Nigeria economic development. As part of the Nigerian Government policy in the provision of infrastructure facility through PPP, the ICRC is to ensure that the private sectors play a greater role in the provision of infrastructure facility, whilst ministries and other public authorities in Nigeria will focus on planning and structuring the various infrastructure projects. The ICRC develops the guidelines, policies, and procurement processes for PPP and also collaborates with the various States in Nigeria to promote an orderly and harmonised framework for the development of infrastructure facilities and to accelerate the development of a market for PPP projects. The private sector is to be contracted to manage some of the public services, and to design, build, finance and operate some of the infrastructure.

The policy is to assure investors in infrastructure development that all contract completed in compliance with the ICRC Act will be legal and enforceable, and that all the investors will be able to recover their expected return subject to compliance with the terms and conditions of the PPP contract. See figures 1a, 1b, 1c and 1d for road development in North-Central region of Nigeria.

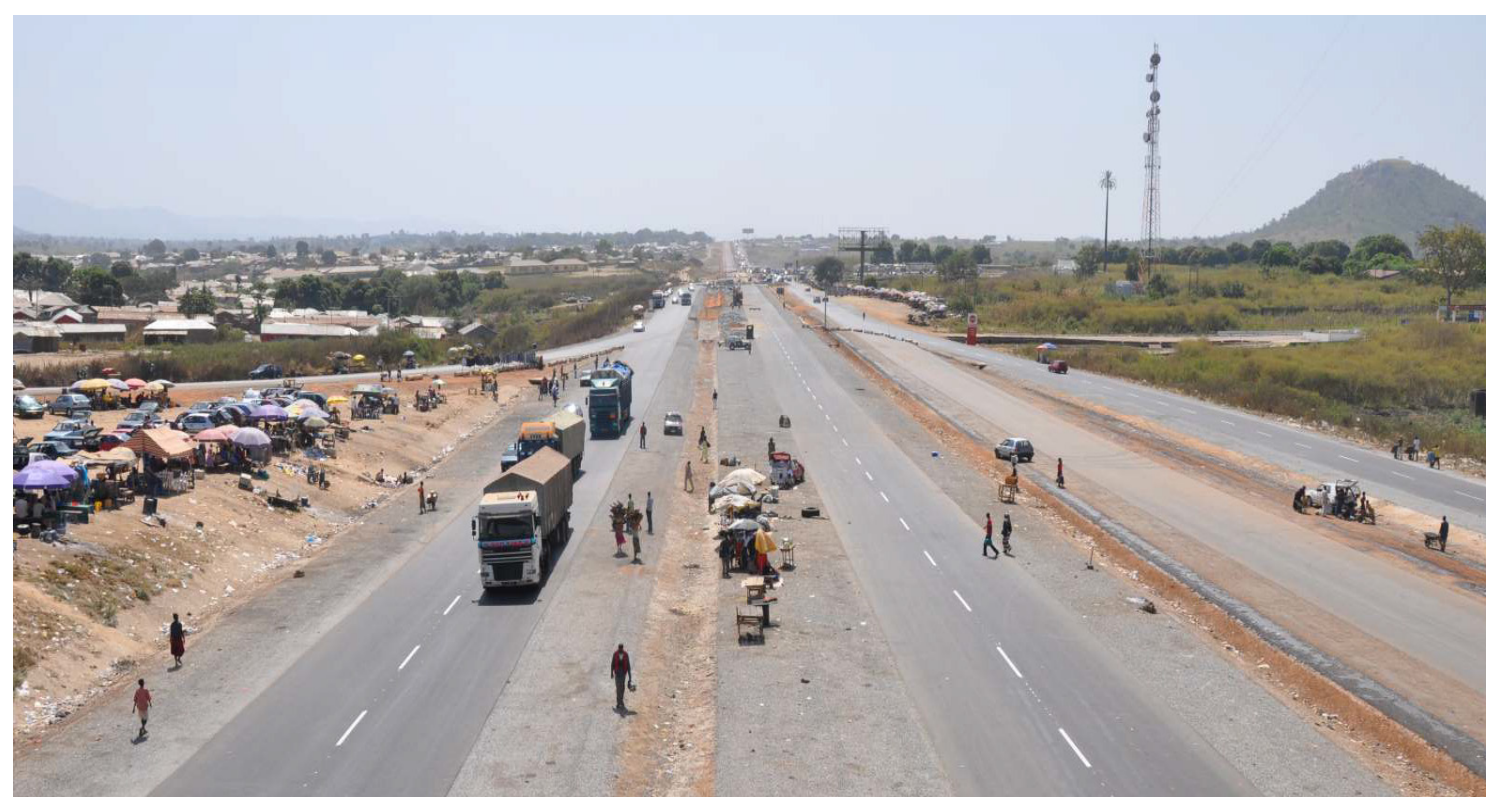

Figure 1(a). Road Development in North-Central Region of Nigeria (Abuja-Lokoja Dual Carriage)

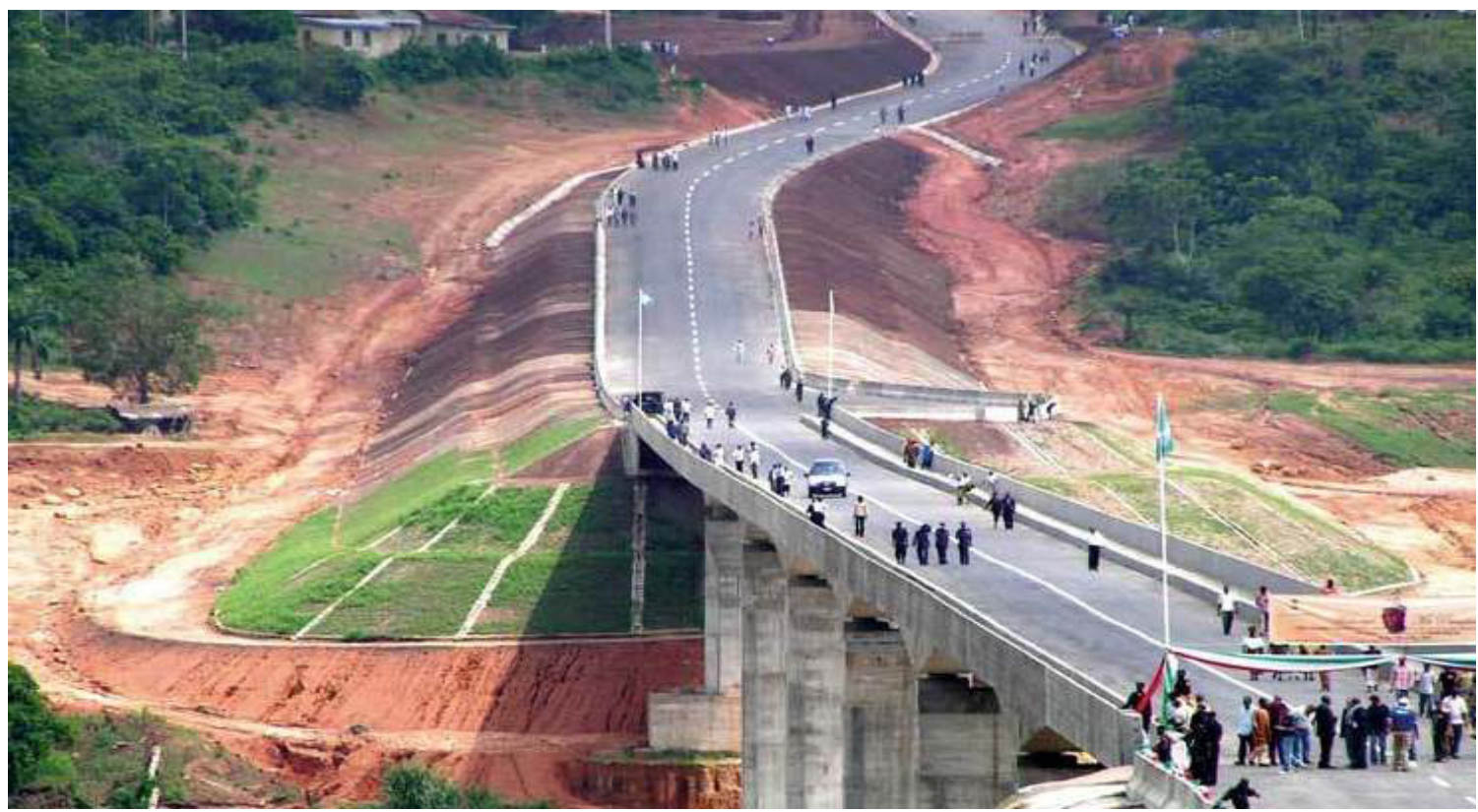

Figure 1(b). Road Development in North-Central Region of Nigeria 


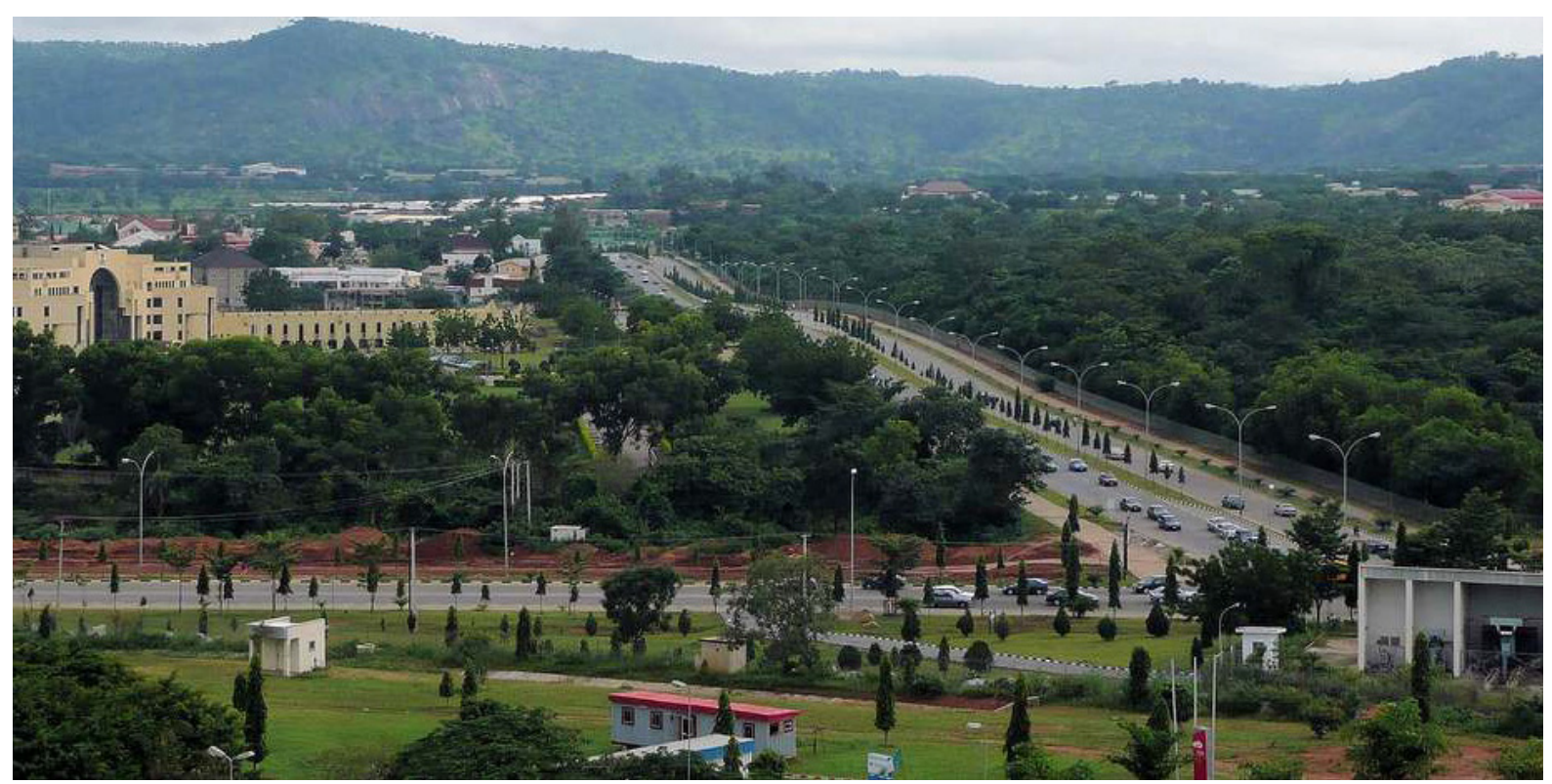

Figure 1(c). Road Network in FCT, Abuja North-Central Region of Nigeria

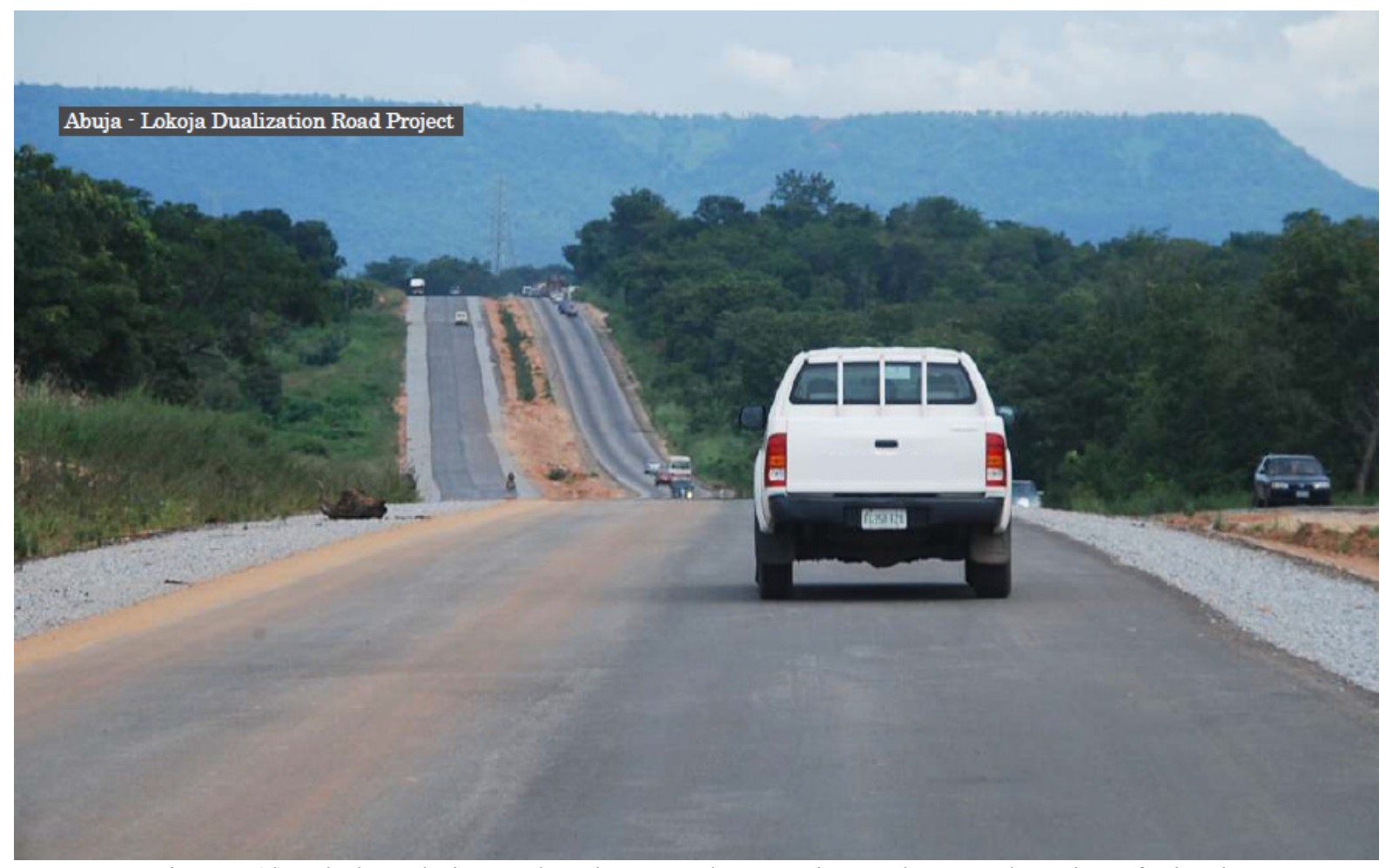

Figure 1(d). Abuja-Lokoja Road Project Development in North-Central Region of Nigeria

\section{PPPs Objectives in Road Infrastructure Development in North-Central Region of Nigeria}

PPP strategies have been employed successfully for decades in countries like Australia, Canada, South Africa, and the United Kingdom and are increasingly being adopted by governments in many other developing countries with the sole objective of increasing access to infrastructure services like road infrastructure (ICRC, 2012; Haran et al., 2013).

According to ICRC (2012), the objective of PPP strategies in road infrastructure development in the north-central Nigeria which is not far from the global goals and objectives of PPP transactions is to increase the availability of road infrastructure facilities in the zone and to do so with greater efficiency than could be achieved through the traditional public approach in road infrastructure development. The goals and objectives of 
the PPPs in road infrastructure development in the north-central Nigeria according to ICRC (2012); Ndubisi (2012) and Adamu et al. (2015) include:

1) Obtaining more value for money invested in the road project;

2) Better and appropriate risk allocation among the stakeholders in the road project;

3) Faster and better project implementation;

4) Improved service and quality delivery;

5) Obtaining additional revenue streams for the economy;

6) Minimizing life-cycle costs and improving cash flow; and

7) Enhancing proper project management and reducing waste.

In order to achieve these PPP objectives, according to ICRC (2012) and Adamu et al. (2015), the PPPs are therefore structured in a manner that allows both the public and private sectors to take on certain roles and enjoy certain advantages in the road infrastructure development relative to each other while performing their specific tasks in the road project development but this could not be achieved. However in order to achieve an efficient road infrastructure development in the north-central Nigeria, the Federal Government of Nigeria provides social responsibility, environmental awareness, regulation, and the ability to mobilize political support for road infrastructure development in the north-central Nigeria (Adamu et al., 2015). Further to this, during the operational life-cycle of the road infrastructure, the public sector also monitors the performance of the private partners to ensure the strict adherent to the terms of the road contract and the road project objectives, but for lack of effective PPP framework that is environmentally, socially and economically friendly to the north-central zone of Nigeria, these are not adequately achieved (Amobi, 2013; WEF, 2013; Adamu et al., 2015). Therefore the private sector's role in this regard will be to make use of its expertise in the commerce, management, operations, and innovation in running the road infrastructure development efficiently (ICRC, 2012; Haran et al., 2013).

\section{PPPs Operational and Financial Characteristics in Road Infrastrucrture Development in North-Central Nigeria}

Road infrastructure development under PPP requires investments that are generally long-term in nature, typically ranging between 10 to 30 years or more so as to achieve the project objectives. In view of this, ICRC (2012) and Essia \& Yusuf (2013) stated that the tenure of road infrastructure project contract is such that it covers the entire economic life-cycle of the road project. The road project will then be designed, constructed, operated and maintained in such that the whole life-cycle cost of the road infrastructure facility is minimized and the private sector operator ensures that the road infrastructure is well-maintained throughout the entire economic life of the road infrastructure in order to achieving the required performance of the road infrastructure (Ugboaja, 2010; Iloh \& Bashir, 2013).

In financing road development in the north-central Nigeria, Amobi (2013) and WEF (2013) observed that the responsibility of financing the road development often rests with the private sector partner in the road development contract and depending on the PPP delivery model adopted. In view of this according to ICRC (2012), the private sector partner raises the road development finance through equity and/or debt finance. In this regard, the road infrastructure is usually owned or leased by one or more equity investors during the project contract term. Therefore in order to make the founding arrangement attractive to the private sector partner in the road development, Viability Gap Funding (VGF) scheme is employed, the public sector provides a payment to part-finance the road development costs which in turn will raise the return to the private sector making the road development more financially attractive to both the public and private partners in the road development contract (ICRC, 2012).

\section{PPP Strategies for Road Infrastructure Development in North-Central Region of Nigeria}

In order to exploit the efficiency and effectiveness of PPP in the north-central, the planners and the stakeholders need to choose an appropriate development strategy for the proposed road infrastructure. According to WEF (2013) and Adamu et al. (2015), the choice may differ from project to project, in making the choice and customizing the development strategy, the stakeholders will have to strike a balance between two considerations: ensuring attractiveness of the project to the private sector; and safeguarding public interests and keeping the overall road infrastructure project economic costs down.

In north-central Nigeria ICRC (2012) and Adamu et al. (2015) noted that there are several PPP strategies in practice but depends on the type of stakeholders involved in the PPP transaction, their ownership arrangements, and allocations of risks between the private and public partners and above all on the objectives of the Federal and 
States Government in the north-central Nigeria in improving service efficiency, transferring investment risks and maintaining service control. Table 1 bellow highlights the major PPP strategies for road infrastructure development in the north-central Nigeria.

Table 1. PPP Development Strategies in North-Central Region of Nigeria

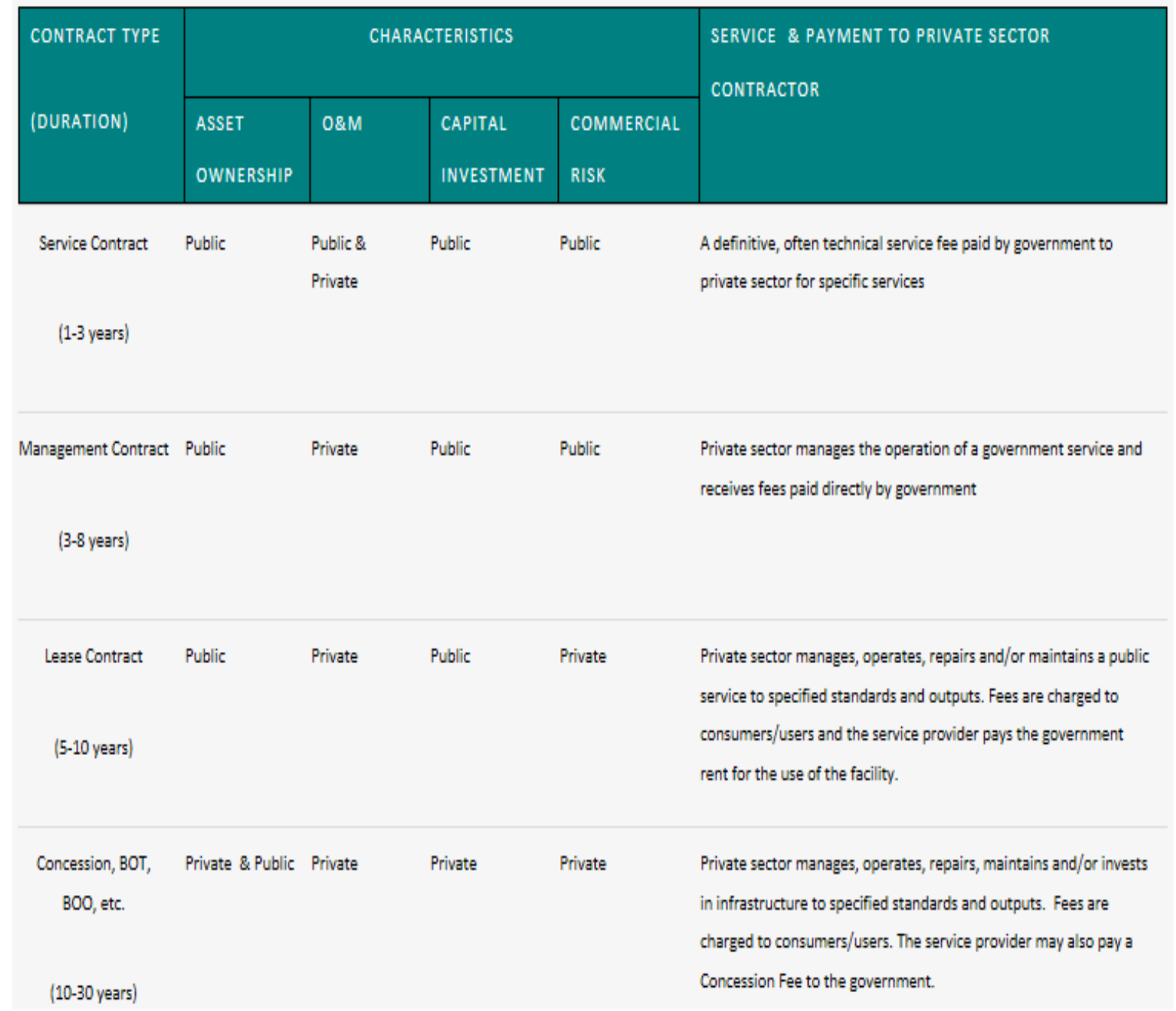

Source: Infrastructure Concession Regulatory Commission (2012).

ICRC (2012) observed that under a contract service, the public sector hires a private company or entity to carry out one or more specified tasks or services for a period, typically one to three years in the development of road infrastructure in the north-central Nigeria. Hence the private partner carries out the road development at the agreed cost which must also meet the performance standards as set by the public sector in the road development contract. While the public partner pays the private partner a predetermined fee for the service provided in the road development. Under Management contracting system in PPP transaction, the transaction involve comprehensive service contract that covers all the management and operational components of road infrastructure development for between three and eight years. Under this form of infrastructure development strategy according to ICRC (2012) and FMW (2013), the ultimate obligation for service provision in the road development remains with the public partner; the daily management control and authority are only assigned to the private partner. While the private partner is paid a predetermined rate for labour and other anticipated operating costs involved in the road development, the public partner provides an incentive for performance improvement in road infrastructure; the contractor is paid an additional amount for achieving pre-specified targets in the delivery of the road infrastructure as set out in the contract agreement in the PPP transaction. 
Under a lease contract procurement system for road infrastructure development in the north-central according to ICRC (2012) and WEF (2013), private partner is responsible for the service of road development and operation in its entirety, the private partner also undertakes obligations relating to quality and standards of the road infrastructure facility. ICRC (2012) further stated that given the increased risk burden on the private sector in road infrastructure development, the contract period of a leasing contract under PPP transaction is usually longer than service and management contract. This form of PPP transaction for road development spans between five and ten years duration.

The concessions procurement strategy for road infrastructure development in north-central Nigeria is in form of Build-Operate-Transfer (BOT) and Build-Own-Operate (BOO) patterns. The concession procurement strategy according to Adamu et al. (2015) recognises the private partner as the concessionaire responsible for the full development of road infrastructure in a specific area; including construction, operation, maintenance, collection, management and rehabilitation of the road infrastructure as required and contained in the contract agreement for a much longer period of between ten and thirty years given the complexity of the procurement arrangement and the need for long-term financing (ICRC, 2012; FMW, 2013; WEF, 2013).But in most cases, the public partner provides financial support in form of Viability Gap Funding (VGF) to help the concessionaire fund its capital expenditure in the road project. ICRC (2012) observed that although the private partner is responsible for the provision of the road infrastructure, the road infrastructure will often remain publicly owned and are returned to the government as the public partner at the end of the concession period as it may be agreed upon in the contract.

In terms of road performance according to ICRC (2012), the public sector is responsible for ensuring that the concessionaire meets performance standard of the road infrastructure while the public sector's responsibility subsequently shifts from being the service provider to regulating the cost and quality of the road infrastructure. Annuity Scheme (AS) is another form of BOT scheme employed for road development in the north-central Nigeria when road development cannot be carried out under BOT or DBFOT basis as a result of low revenue due to low traffic or high cost of road development and when the road infrastructure facility is required for security reasons or for the development of a particular area in the zone (FMW, 2013). Under the annuity development strategy according to FMW (2013), the private concessionaire finances and undertakes the development and maintenance of the road infrastructure and the recovery of all the investment plus a predetermined rate of return from the annuity payments by the public investors or granting authority. The annuity-based procurement strategies are granted through a tender process in which the lowest annuity requested is used as a bidding criterion for the road development

\section{PPP Challenges in Road Infrastructure Development in North-Central Region of Nigeria}

As the implementations of PPP strategies in north-central region of Nigeria are becoming increasingly popular for both new development and management of old infrastructural facilities in the zone, however many infrastructure projects especially road infrastructure project that had been developed through PPPs have failed (Sanusi, 2012; Adamu et al., 2015). One of the key factors to achieving successful implementation of PPP strategy in road infrastructure development in north-central region of Nigeria according to ICRC (2012) Ugboaja, (2010) and Iloh \& Bashir (2013) is the optimal sharing of risks and responsibilities between the public and the private sector in the road development. In view of this, the guiding principle adopted in identifying and allocating responsibilities in the PPP transaction should be that the party best able to manage a particular activity should be responsible for the risks associated with that activity and receive the associated rewards or losses.

In recognition of the challenges associated with the road infrastructure projects procured under PPPs, the Federal and States government within north-central region of Nigeria had made great progress in establishing mechanisms and frameworks for PPP implementation. These include the adoption of the Infrastructure Concession Regulatory Commission (ICRC) Act in 2005 and the subsequent creation of the ICRC office, the enactment of National Policy on PPPs in the year 2009 and the formulation of Public-Private Partnership Regulations in 2011. These are geared towards dealing with the current and the impending challenges facing the development and management of road infrastructure development under PPP strategy in north-central region of Nigeria (Sanusi, 2012).

In a related development, Ameh et al. (2010); Sampath (2013) and Adamu et al. (2015) listed the key challenges of Public-Private Partnerships (PPPs) strategies employed for the road infrastructure development in north-central region of Nigeria to include:

1) PPP procedures and processes; in securing competitive bids, negotiation and award,

2) Appropriate allocation of risks and responsibilities to investors, 
3) management of the inherent risks and the inhibiting risk factors, associated with road infrastructure development in north-central region of Nigeria,

4) Poor enabling PPP environment for road infrastructure,

5) Poor internalising PPP process within the public sector at the Federal and State government structure in north-central region of Nigeria,

6) Poor project identification and development processes for road development,

7) Poor road infrastructure business case, and

8) Poor PPP support, implementation and operations by the investors.

Ndubisi (2012); Amobi (2013) and Adamu et al. (2015) further noted that the impact of Public-Private Partnership (PPP) development challenges on road infrastructure projects in north-central Nigeria which has led to very high cost and time overruns in the road development where also attributed to lack of capacity and political will to enforce the existing regulatory and institutional framework for Public-Private Partnership (PPPs) in the north-central Nigeria. To this end, Ndubisi (2012) and Adamu et al. (2015) reviewed some of the road infrastructure developed under PPP in north-central region of Nigeria and identified the issues and challenges of the road infrastructure development to include;

1) lack of national infrastructure blueprint,

2) unclear political direction and support,

3) weak regulatory and enforcement powers of ICRC,

4) inadequate financial modelling for proper affordability and value for money assessments,

5) technical capacity gaps,

6) lack of effective institutional framework for PPP project preparation,

7) inconsistency in the PPP project pipelines, and

8) Lack of standardisation, hindering replication, etc.

Ijigah et al. (2012) and Amobi (2013) also reiterated that the most pressing development challenges of road infrastructure development under PPPs in the north-central Nigeria was the lack of effective PPP project preparation and acceleration towards bankability, this because the private investor are holding onto substantial road assets under their management, for which they are seeking attractive long-term investment opportunities on the road assets in the zone. As a result of this attitude on the part of the private investors, many road projects became stalled in the pipeline and have failed to get off the ground. The reason according to Federal Ministry of Works (2013) is the road project preparation gap which include;

1) the shortage of well-prepared bankable PPP road development where investors are sufficiently reassured by the commercial and technical feasibility,

2) the inadequate risk and responsibilities allocation,

3) the poor public sector's contractual commitment and capacity,

4) inadequate demand forecasts,

5) delayed land acquisition and approval, and

6) Ineffective institutional and regulatory framework for PPP road development.

\section{Conclussion}

This study examined the concept of road infrastructure development through Public-Private Partnership and challenges impacting on the successful implementation of the development strategies in north-central region of Nigeria.

The adoption of PPP strategy has been instrumental to reducing the financial burden on the Federal and State government within north-central region of Nigeria in response to the increase demand for more road infrastructure coupled with the bad state of the existing roads in the zone by allowing the public sector to be the facilitator and framework regulator while the private sector are involved in the funding, construction and management of the road infrastructure which have been hampered by the inefficient and ineffective PPPs institutional and regulatory framework for road development in north-central region of Nigeria. This paper examined state of road infrastructure development and the various objectives of Public-Private Partnership (PPP) 
in north-central region of Nigeria. This study also examined the operational and financial characteristics of road infrastructure project development through PPPs in order to identify the challenges impacting on the effectiveness and efficiency of PPP institutional and regulatory framework, this was followed with the assessment of the PPP strategies employed for road development in north-central region of Nigeria. The findings of the study revealed that the development of road infrastructure has been on joint venture arrangement between the public and the private sectors inform of Public-Private Partnerships, the findings further revealed that the key challenges affecting the effectiveness and efficiency of the Public-Private Partnerships in road infrastructure development in north-central region of Nigeria centred around the PPP institutional and regulatory framework in the areas of ; (i) project preparation management process, (ii) project bankable feasibility study, (iii) balance risk allocation and regulation, and (iv) enabling project environment. This has resulted to the poor social-economic development of the area in terms of good and human transportation and the general development of the zone. In order to improve on the social-economic development of the zone, the Federal and State Government within the zone will require about US\$6 billion investment in road infrastructure provision within the next few years in the area.

The study further revealed that the efficiency and effectiveness of PPP strategies in road development in the zone will depend upon the ability of the public sectors in the zone in addressing the key challenges of the PPP institutional and regulatory framework. The study therefore concluded that the current PPP institutional and regulatory framework for road infrastructure development in north-central region of Nigeria needs to be reviewed so as to enhance the effectiveness and efficiency of PPPs in road development in the region.

\section{References}

Adamu, M., Lowe, J., \& Manase, D. (2015). Conceptual Framework for Public-Private Financed Road Infrastructure Development in Nigeria. International Journal of Engineering Research and Technology, 4(8), 586-590.

Adenikinju, A. F. (2003). Electric Infrastructure Failures in Nigeria: A Survey-Based Analysis of the Costs and Adjustment Responses. Energy Policy, 31, 1519-1530. http://dx.doi.org/10.1016/S0301-4215(02)00208-2

Akinyosoye, O. (2010). Nigeria's Infrastructure: Investment Opportunity for Fiduciaries of Pension Funds (pp. 1-28). Greenhill Technical Services Ltd.

Ameh, O. J., Soyingbe, A. A., \& Odusami, K. T. (2010). Significant Factors Causing Cost Overruns in Telecommunication Projects in Nigeria. Journal of Construction in Developing Countries, 15(2), 49-56.

Amobi, I. C. (2013). Public-Private Partnership as a Model for Infrastructural Development in Nigerian Universities. A paper presented at the Maiden Lecture of the Annual Lecture Series of the Department of Economics, Nnamdi Azikiwe University, Akwa Nigeria, African Heritage Institution, pp.1-10.

Dada, M. O., \& Oladokun, M. G. (2012). Analysis of Critical Success Sub-Factors for Private-Public Partnerships in Nigeria. AlamCipta, 5(2), 13-26.

Essia, U., \& Yusuf, A. (2013). Public-Private Partnerships and Sustainable Development of Infrastructure in Nigeria. Advances in Management and Applied Economics, 3(6), 113-127.

Federal Ministry of Work. (2013). Compendium Report on Road Infrastructure and Related Development in Nigeria. PISION Abuja.

Haran, M., Adair, A., Berry, J., Cord, M., McGreal, S., Smyth, C., ... Hutchison, N. (2013). The Global Infrastructure Challenge: The Role of PPP in a New Financial and Economic Paradigm. Retrieved from www.rics.org/research

Howes, R., \&Tah, R. H. (2007). Strategic Management Applied to International Construction. London: Thomas Telford Publishing, 1 Heron Quay.

Ijigah, E. A., Oloruntoba, K., \&Mohn, H. R. (2012). Towards Accomplishing Millennium Development Goals (MDGs) in Abuja, FCT Nigeria: The Project Management Consultant Roles.

Iloh, J. O., \& Bashir, M. (2013). Public-Private Partnerships and Social Service Reform in Nigeria: 1999-2007. Journal of Education and Social Research, 3(10), 101-108. http://dx.doi.org/10.5901/jesr.2013.v3n10p101

Infrastructure Concession Regulatory Commission. (2012). Nigeria Public-Private Partnerships Manual. ICRC PPPToolkit.

Ndubisi, C. (2012). Public Private Partnership: The Nigerian Experience. Paper presented at the Capacity Building Programme for PPP in Infrastructure, ICRC Mbamene, Swaziland July 2012. 
Obozuwa, D. E. (2013). PPP as a Tool for Development in Nigeria. FPPPN Admin.

Omisore, S. (2014). What Makes an Infrastructure Project Bankable. Infrastructure Stakeholders Forum, Stanbic IBTC.

Sampath, S. (2013). Challenges and Issues in Structuring and Managing PPs: What Should the Pulic Sector Know About? Paper Presented at a workshop on Mainstreaming Public-Private Partnerships in Urban Sector, Taj Krishna Hotel, Hyderabad.

Sanusi, L. S. (2012). The Role of Development Finance Institutions in Infrastructure Development: What Nigeria can learn from BNDES and the Indian Infrastructure Finance Company, Keynote Address; 3rd ICRC PPP Stakeholders Forum.

Ugboaja, P. C. (2010). Sustainable Rural Transportation in Nigeria through Public-Private Partnerships. Interdisciplinary Journal of Contemporary Research in Business, 2(3), 199-217.

World Economic Forum. (2013). Strategic Infrastructure: Steps to Prepare and Accelerate Public-Private Partnerships. May Edition, Boston Consulting Group.

\section{Copyrights}

Copyright for this article is retained by the author(s), with first publication rights granted to the journal.

This is an open-access article distributed under the terms and conditions of the Creative Commons Attribution license (http://creativecommons.org/licenses/by/3.0/). 